\title{
Rhodococcus 工業生産菌のニトリル分解遺伝子群の解析と応用
}

Analysis and application of the gene cluster involved in nitrile degradation of industrial Rhodococcus

筑波大学大学院生命環境科学研究科
橋本 義輝 Yoshiteru HASHIMOTO
戸来 幸男 Sachio HERAI
東端 啓貴 Hiroki HIGASHIBATA
小林 達彦 Michihiko KOBAYASHI

Key words: Hyper-inducible expression; nitrilase; nitrile hydratase; Rhodococcus; Streptomyces

\section{1.はじめに}

Rhodococcus 属放線菌は有用物質を生産する微生物之 してだけでなく，近年，芳香族化合物や塩素系化合物に対 し高い分解活性を示す微生物之して知られている。筆者ら は，毒性化合物であるニトリル11执よびイソニトリル2》31の 微生物代謝研究を行ってきており，特に，これまで研究対 象としたRhodococcus rhodochrous J1 菌 (以下, J1 菌と 略）はすでに（アクリロニトリルからの）アクリルアミド や（3-シアノピリジンからの）二コチンアミドの工業生産 に使用されるに至っている. 現在, 本菌のみならずさまざ まなRhodococcus 属微生物の高い潜在能力がさらに広範 囲の物質生産や環境浄化に還元されることが期待されてい る.

\section{Rhodococcus 属工業生産菌のニトリル分解経路に かかわる酵素の誘導発現}

J1 菌に打ける（猛毒性の性質を与えるシアノ基を含む） ニトリル化合物の分解代謝は二つに大別できる(図 1)。一 つは，ニトリラーゼ酵素によりニトリルが酸とアンモニア に分解される経路であり，あう一つは，ニトリルヒドラ夕 一ゼ䣼素 (以下, NHase 上略) ${ }^{4)}$ によりニトリルはいった んアミトに分解され, その後, アミダーゼ酵素により酸よ アンモニアに分解される経路であるが, 培地へ添加する誘 導物質の種類を変えることにより本菌のニトリル分解様式

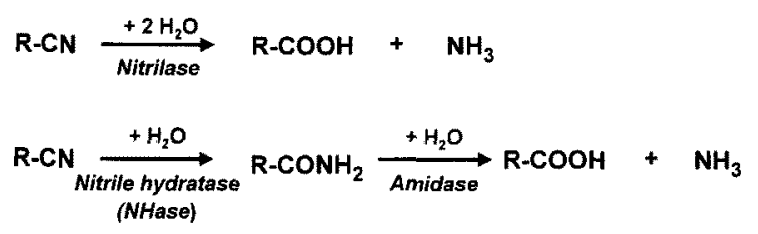

図12 種類のニトリル分解経路
はがらりと変わる。すなわち，培地にイソバレロニトリル (あるいはと-カプロラクタム) 在誘導物質として添加した 場合, ニトリラーゼが無細胞抽出液の $35 \%$ 以上を占める ほど大量に生成する。一方，コバルトイオン存在下で，培 地に尿素を誘導物質として添加した場合, 高分子量型 NHase (以下, H-NHase と略) が生成し, 同じく,コバル トイオン存在下で, 培地にシクロヘキサンカルボキサミド を誘導物質として添加した場合には, 低分子量型 NHase (以下, L-NHase と略) が生成する5!. 特に, H-NHase の生 成は無細胞抽出液の $50 \%$ 以上を占力る。このように, ニト リラーゼのや H-NHase ${ }^{7)}$ の遺伝子プロモーターは非常に強 力な転写活性をむつことが示唆されたことから，筆者らは 本菌のニトリル代謝酵素を対象として，世界で初好て Rhodococcus 属のプロモーターを同定, 転写開始点の決定 を行い,デリーション実験やノーザン解析などにより DNA·RNA 両レベルで各醉素の遺伝子発現調節機構を解 明した。

\section{Rhodococcus 属に由来する誘導型発現系のStrep- tomyces 属放線菌への利用}

一方, Streptomyces 属放線菌は, 生理活性物質生産菌之 して工業的に広く利用されており, 今日の応用微生物学 上, 極めて重要な菌群となっている. Streptomyces 属での 有用物質生産の重要性に鑑み, 現在, 本属において発現が 制御可能な誘導型の大量発現系の開発か望まれている。実 際, Streptomyces 属放線菌に抢いて誘導性プロモータ一を 利用した報告例はほ上んどない(8).99.しかし，これらは(1)発 現が微弱である，(2)宿主域が狭い，(3)2次代謝産物に代表 される有用物質生産に悪影響を及ぼす可能性が考えられる 抗生物質を誘導剤として用いる，などさまざまな問題点が 存在するために, その有用性は極めて限られているのが現 状である。また，これを改良する誘導発現・大量発現の報 告例屯これまでにない。

筆者らは, J1 菌のニトリラーゼやH-NHase の（Rhodo- 
1074 ミニレビュー

coccus 属由来の) 遗伝子プロモーターが Streptomyces 属 でも機能すれば面白い上思い，研究存行った，まず，J1 菌 のニトリラーゼ采を対象とし、ニトリラーゼの構造遺伝子 (nitA) とその制御遺伝子 (nitR) 古屯に, Streptomyces 属 用プロモーター検索ベタターに㨂入し，S. lividansを形質 転換させた結果, Rhodococcus 属の誘導型発現調節機構が Streptomyces 属に扔いて屯働くことが初めて明らかにな った。また，誘導的に発現したニトリラーゼは全可溶性夕 ンパク質の 20\%に達し, Streptomyces 属においても本誘 導発現系が極めて強力に機能することが判明した，本発現 調節に必要とされる最小領域の決定を目的として，デリ一 ション実験および Streptomyces 属放線菌内での発現を検 討した結果, ニトリラーゼ遺伝子プロモーター(PnitA $) \cdot$ 転写調節タンパク質 $(\mathrm{NitR})$ ・誘導剤という極めてシンプ ルな構成要素のみで本誘導発現系が機能することが明らか となった，次に，得られた結果を基に，ニトリラーゼ誘導 発現系在用いた新規誘導型タンパク質発現采 (Pnit $A^{-}$ NitR)（図 2) を保持する高発現ベクター pSH19（図 3）の 構築存試みた10!. 本発現系 (図 2) はマルチクローニングサ イト扝よび nitR 遺伝子のすぐ上流にP P nitA を，また上流 からの転写のリードスルーを防ぐために $\mathrm{P}_{n i t A}$ の上流に は夕ーミネーターを配置した，本べクタ一系を利用した発 現系では，誘導物質在添加することにより転写活性化タン パク質NitRが目的タンパク質の発現を顕著に促進するだ

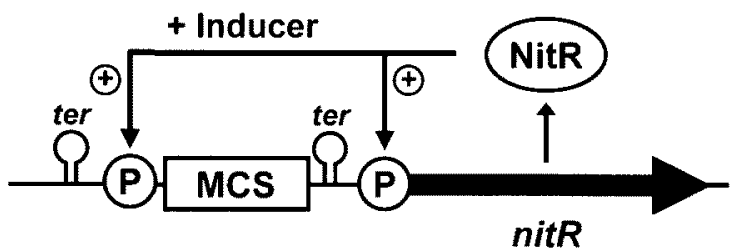

図 2 新規誘導型発現系 (PnitA-NitR 系)

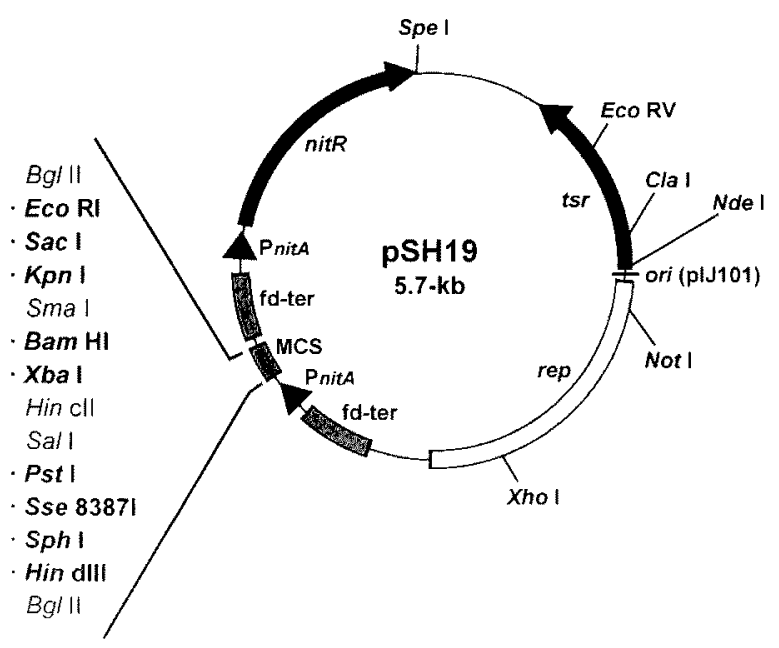

図 3 誘䭫発現ブラスミドpSH19
(Nippon Nögeikagaku Kaishi

けでなく, NitR 自身の発現も促進し，そこに再び誘導物質 が作用することで, 目的タンパク質の自己增幅的な発現が 期待できる。

この新規発現系を用いて翼種タンパク質の発現を試みた 結果，グラム陽性細菌由来の二トリラーゼのみならず，グ ラム陰性細菌由来のカテコール-2,3-ジオキシゲナーゼ ${ }^{11)}$, イソニトリルヒドラターゼ21なよ゙のタンパク質の誘導的な 大量発現に成功した。 カテコール-2,3-ジオキシゲナーゼ は，全可溶性タンパク質の $40 \%$ に及ぶ極めて著量の誘導 的生成が確認された。PnitA-NitR 系は，この系に含まれ る構成要素が最小単位であり, 従来報告のあるtipA プロ モーターの上うに誘導発現に際し transに䡃く他の染色体 由来因子を必要としない，このため，PnitA-NitR 系を保 持するプラスミドが複製するすべての放線菌で利用可能と 考えられる. 奏際, 本発現系がS. lividans のみならず，ゲ 人ム情報解読の完了したStreptomyces avermitilis ${ }^{131} や$ Streptomyces coelicolor A3(2) $)^{14)}$, 学術研究で汎用される Streptomyces griseus よ゙幅広い宿主で機能することを確 認した。

一方，尿素により誘導がかかるH-NHase に関しては， 本遺伝子 $(n h h B A)$ 発現にその上流域が必須であり，本領 域には, 大腸菌由来の調節遺伝子 $\operatorname{mar} R や h p c R$ 之相同性 を示す遺伝子 $(n h h D)$ 之, Pseudonomas aeruginosa のアミ ダーゼの負の調節遺伝子である $\mathrm{amiC}$ 之相同性を示す遺伝 子 $(n h h C)$ が存在する。また,これらの調節遺伝子は，ア、 ド化合物（尿素など）によるnhhBA の誘導発現において 転写レベルでの制御にかかわっている，このH-NHase 遺 伝子クラスターに関してひ、ニトリラーゼと同様に, E. coli-Streptomyces シャトルベクターを用いて S. lividans を形質転換させ，誘導剤として尿素を培地に添加して検討 した結果, H-NHaseの著量発現が確認できた。しかしなが ら，その発現は誘導的ではなく構成的であり, 現在, さら に検討を進めている。

\section{4. おわりに}

Rhodococcus 属のニトリラーゼ㧍よびニトリルヒドラ ターセ遗伝子プロモーターを利用した発現系における著量 のタンパク質生成は従来までに報告されているいかなる Streptomyces 属タンパク質発現系をむ凌駕する. PnitANitR 誘導型発現系は, Streptomyces 属放線菌の基礎研究 用ッール，例えば大腸菌に招けるlacプロモーター系や pET システムなどのような遺伝子発現の制御やタンパク 質の大量発現ッールとして利用できる。近年相次いでゲ， ム情報解読がなされ今後ますます盛んになるポストゲノム 研究, 特に, タンパク質の機能解析に扔いて, その能力が 
Vol. 78 , No. 11,2004$]$

いかんなく発揮されることが期待される.

またここれらの発現系を用いることで種々の有用タンパ 質・生理活性物質の生産性が向上したStreptomyces 属 放線菌の育種改良が期待される。筆者らは, Streptomyces 属放線菌での「あの作り」, すなわち誘導剂の安全性やコス 卜を当初加ら念頭に执き， $\varepsilon$-カプロラクタムや尿素のよう に毒性汃低くかつ安価な物質を誘導剂として使用可能な PnitA-NitR 系を構築した。幅広い宿主域をもつ特性が最 大限に活用され，本発現系が多くの放線菌の育種改良・物 質生産に広く利用されれば幸いである。

本研究は, 池田治生教授, 大村 智教授（北里大学生命 科学研究所）との共同研究で達成されたもので, 懇切なご 助言を賜り心より感謝申し上げます。ささらに, 研究を行い 多大なご協力をいただいた株本浩樹君，廣石綾子さん，間 世田英明助手に厚くお礼申し上げます。

本研究は，新エネルギー・産業技術総合開発機構 (NEDO) 産業技術研究助成事業からサポートをいただきま した：ここに厚く括礼申し上げます。なお，本研究は 21 世 紀 COE プログラム「複合生物系応答機構の解析と農学的 高度利用」プロジェクト (http://www.tara.tsukuba.ac. $\mathrm{jp} / \sim \operatorname{coe} 21 /$ ) (生命科学領域) の一環として行ったもので ある。

1) M. Kobayashi and S. Shimizu: Nature Biotech., 16, 733736 (1998).

2) M. Goda, Y. Hashimoto, S. Shimizu, and M. Kobayashi: J. Biol. Chem., 276, 23480-23485 (2001).

3) H. Fukatsu, Y. Hashimoto, M. Goda, H. Higashibata, and M. Kobayashi: Proc. Natl. Acad. Sci. U.S.A., 101, 1372613731 (2004).

4) Y. Asano, Y. Tani, and H. Yamada: Agric. Biol. Chem., 44, 2251-2252 (1989).

5) M. Kobayashi, T. Nagasawa, and H. Yamada: Trends Biotechnol, 10, 402-408 (1992).

6) H. Komeda, Y. Hori, M. Kobayashi, and S. Shimizu: Proc. Natl. Acad. Sci. U.S.A., 93, 10572-10577 (1996).

7) H. Komeda, M. Kobayashi, and S. Shimizu: Proc. Natl. Acad. Sci. U.S.A., 93, 4267-4272 (1996).

8) T. Schmitt-John and J. W. Engels: Appl. Microbiol. Biotechnol., 36, 493-498 (1992).

9) E. Takano, J. White, M. J. Thompson, and M. J. Bobbs: Gene, 166, 133-137 (1995).

10) S. Herai, Y. Hashimoto, H. Higashibata, H. Maseda, H. Ikeda, S. Ōmura, and M. Kobayashi: 101, 14031-14035 (2004).

11) C. Nakai, H. Kagamiyama, M. Nozaki, T. Nakazawa, S. Inoue, Y. Ebina, and A. Nakazawa: J. Biol. Chem., 258, 2923-2928 (1983).

12) M. Goda, Y. Hashimoto, M. Takase, S. Herai, Y. Iwahara, H. Higashibata, and M. Kobayashi: J. Biol. Chem., 277, 45860-45865 (2002).

13) H. Ikeda et al:: Nature Biotech., 21, 526-531 (2003).

14) S. D. Bentley et al:: Nature, 417, 141-147 (2002). 